\title{
The role of traditional education in the cultural life of turkestan: problems and reforms (Second half of 19 - beginning of 20 century)
}

\author{
Ziyaeva Dono Khamidovna ${ }^{1}$ \\ ${ }^{I}$ Doctor of historical sciences, professor, Institute of History of the Academy of Sciences of the \\ Republic of Uzbekistan, Uzbekistan \\ Email:_ziyayeva_d@umail.uz
}

\begin{abstract}
In this article, the second half of the 19 century - the beginning of the 20 century, the cultural life of the Turkestan country is widely covered by the example of the educational system. Schools and madrassahs, which are considered part of traditional education, provide full information about the pedagogical process, providing detailed information on educational activities, software, the list of subjects to be taught, as well as textbooks. Also, the author studied the problems existing in the educational system of that period and analyzed the ways of their elimination.

In this regard, the role of representatives of the educational sphere in the society, the opportunities created for students and educators are mentioned, and the specific position of the educational system in the cultural life of society is widely covered.
\end{abstract}

Keywords: Turkestan, culture, schools, madrasahs, education, upbringing.

\section{INTRODUCTION}

It is not surprising, of course, that in the Central Asian region, which has had a significant impact on the development of world civilization from ancient times, many scientists and wise people have grown up. The great attention paid to education and training in the region has provided a solid foundation for this. Even in the second half of the 19th and the beginning of the 20th centuries, the traditional education system had its own way and development and was gaining popularity among the people.

The education system during this period was not only unique, but also a number of disadvantages. For example, the lessons taught to the students of science did not coincide with the demands of the time. Delays in curriculum and textbook reform have had a significant impact on the content and purpose of education. Some prejudices and ideologies in the education system have been hindered by the madrassa teaching secular subjects. Nevertheless, the traditional education system has continued to train the specialists required for modern science and culture.

Such educational centers as "school and madrasa", which occupy a great place in the pedagogy of the peoples of the East, have made a great contribution to encourage the people to become educated as an integral part of educational life, encourage the acquisition of knowledge and popularize the ideas of enlightenment over the centuries.

\section{VIEW OF LITERATURE}

School and Madrasah Education were studied and interpreted differently by different group of researchers. The study by various group researchers over the centuries shows that this topic has acquired actual significance.

The first group of researchers lived and operated during that period I. Geyer, G,Girshfeld, S.Grameniskiy, V.Nalivkin, N.Ostroumov, A.Khanikov, A. Khoroshkin. It is possible to include in the works of a number of Russian servicemen and researchers, such as A.Xoroshkin. Since they personally monitor and witness the events of the period, their works also serve as a source on the topic. Another group of sources that provide rich information about the history and culture of this period can also be cited as archival materials (funds of the Central State Archive of the Republic of Uzbekistan). 
The second group of researchers includes works of local intellectuals such as Ahmad Donish, Mahmudkhoja Behbudi, Sadriddin Ayni, and Abdurauf Fitrat. Also published in periodicals, such as “Ойина”, “Таржимон”, “Туркестанские ведомости” , also help to clarify many new perspectives on the subject.

Another group of studies is organized by the works of tourists and scientists who visited from abroad during this period. From French researchers, Charles Ejen Ujfalvi Kovezd (Charles-Eugène Ujfalvy de Mező - Kövesd, 1842-1904), Gabriel Bonvalo (Pierre Gabriel Bonvalot, 1853-1933), Henry Moser (Henry Moser, 1844-1923), Gyugo Kraft - (Hugues Grafft, 1853-1935), Antoine Joseph Kastane (Joseph-Antoine it is possible to indicate the work of such researchers as Castagné, 1875-1958). At present, the education system in Turkistan is also comprehensively illuminated in the works of English researchers Arminiy Vamberi (Arminius Vamberi, 1832-1913), Fredrik Byababe (Frederick Burnaby, 1841-1895), Henry Lansdell (Henry Lansdell, 1841-1919 years), Yujen Skayler (Ejen Schuyler, 18401890), which are in Turkistan.

\section{RESEARCH OBJECTS}

The cultural life of Turkistan, especially the study of the education system on the basis of historical sources, is to give an objective light of the coverage of the activities of schools and madrasahs on the pages of our long history. Also to identify the causes and consequences of the existing deficiencies in the education system of that period. Awareness of the general public about the features of the traditional education system.

\section{RESEARCH METHODOLOGY}

The study relied on various historical methodological approaches. As this topic, especially in the field of cultural and enlightenment news, relies on historical objectivity as well as objective source analysis.

\section{RESULTS AND DISCUSSION}

The educational system, which was formed and developed in the region with the decisionmaking of the Islamic religion, also reigned in the tradition of the past centuries. According to this tradition, the education system consisted of two stages - schools (primary education) and madrasahs (secondary and higher education).

The primary school system is focused on literacy in Arabic, learning basic arithmetic, teaching ethics and the basics of Islam. In the cities and villages of the country and in the neighboring neighborhoods, there was certainly a school in the neighborhood. . In addition, schools were established in private homes, or in special buildings erected by the community or community members to raise money. The renovation or maintenance of schools was also financed by private donations, with the financial support of students, and the proceeds of the foundation's funds for schools and mosques and madrasas, which were not funded by the state.

The average number of students in schools is 30 to 40 people, and they are between 6 and 15 years of age. Girls' schools are organized in homes, mainly by educated women - otinbibi and otinoy. Inspector of Educational Institutions V.P. Nalivkin acknowledged in the early 1890s that "although the number of schools is 5,000, it is likely that they are 10,000." As the nomadic Kyrgyz auls in the Ferghana and Ettisuv regions usually moved from place to place. In the 1914 report of the Fergana regional public education administration, it was noted that the creation of an accurate list of schools of settlers was complicated, the number of which was not tens, but hundreds . By the beginning of the XX century, 7047 primary schools were functioning in Turkistan.

In schools, the curriculum is aimed at mastering reading and writing in Arabic spelling. After the release of the literacy," Haftiyak", that is, a small Sura from the Kuran Karim, the book" Farzi-Ayn", which teaches the obligatory practices of Islamic religion, and then the book" Chor Kitab "("Chahor Kitab"), which consists of four parts, is written in Persian. In the direction of religious and moral education, the main training course was completed after the book "Sabot ul-ojizin", which was written in the Turkic language, in the poetic style, described as "the Core of the Qur'an". In schools under experienced schoolchildren, pupils studied and memorized the works of representatives of classical literature on the basis of poetic collections in Persian and Turkish languages, which are written in Mirzo Abdukadir Bedil, Alisher Navoi, Fuzuli, Mashrab, Hofiz Sherozi .

Pupils who have been studying at school have gone to writing exercises and it took a year or two. Thus, the duration of study in primary schools lasted four years for learning to read and write. The 
student, who mastered the school curriculum, voluntarily continued his studies to prepare for madrassa education. The other students graduated from high school and were busy with life's anxieties. This syllabus was common to the Khiva and Bukhara khanates, and to all schools in the Turkestan Governorate. Its foundations are Arabic alphabet and writing, mastering elementary arithmetic, learning the basics of Islam, and religious moral education.

At the school of girls, the house was established to produce literacy in the Arabic alphabet, "it was founded on the basis of a training course on the mastering of ironic reading from the Holy Quran. Depending on the level of the schoolboy, a lot of attention is paid to the assimilation of classical literature samples, Persian-Tajik and Turkish language to the students. From successful mastering of schools, poets were trained by talented girls. In addition to the release of literacy in the educational process, attention is paid to the upbringing of girls, the preparation of them for marriage. Such manuals as" banot of Education"," muosharot's manners"," educated wife " were aimed at the formation of eastern moral culture. In some schools, the craft of Sewing was taught to girls from the age of 11-15 years .

The conditions at the schools were far behind the requirements of the time. According to Sadriddin Aini, educated at such schools, the school's rooms are narrow, damp, poorly lit and heated, with no student conveniences, and they are sitting on the mattress on the floor. The age and talent of the student are not given much attention during the study. One of the biggest problems was that the curriculum and manuals had not been improved for centuries, the timing of its implementation was not strictly controlled, the level of knowledge was ignored, and secular conditions remained at the medieval level. The books that were taught at school were in Arabic, Persian, and partly in Turkish, and were difficult for a student who did not yet know the grammar and rules of their native language.

Madrasahs. The next stage of the education system is madrassas, which are considered to be secondary and higher education institutions. The madrasahs are divided into three categories: small, medium and large madrasas, depending on their size, material support, and income from foundation properties. For example, there were about 200 madrassahs in Bukhara in 1914, of which 33 were large, 39 median and the other small.

The madrassas are divided into "adno" (elementary), "avsat" (middle) and "excellent" (upper) depending on the stages of study. Each phase typically took 3 years or more. At each stage, students were provided with scholarships, and as the level of study increased, the scholarship increased. Only those students who want to become teachers, judges, mufti and scholars have completed these three stages in the future. The course of each madrassah was marked by its founder and approved by the judge or khan. In 1890-1893, there were 214 madrassahs in Syrdarya, Ferghana and Samarkand provinces of Turkestan, 155 of which were located in cities and 59 in districts. At the beginning of the 20th century, there were 350 madrasahs in the Bukhara Emirate, 65-70 madrassas in the Khiva Empire, and 336 madrassahs in the governorship of Turkestan. The madrasahs are mainly in the cities. For example, there were 22 madrasahs in Tashkent, 19 in Samarkand, 37-39 in Kokand, and 20 in Namangan. The madrasahs of Bukhara, Tashkent and Samarkand are very popular not only in the region but also in the Muslim world. In Turkestan, the number of students at madrassas was up to 200 or more, depending on their size. On average, they numbered more than 40,000 .

In the middle of the XIX century in Bukhara. According to Janikov, the total number of students in the city's madrassah was 10,000, but in the 1860s, Herman Shamberi noted that there were up to 5,000 students, including students from India, Kashgar, Afghanistan, Russia, and China.

The training process in madrasahs lasted 6 months (from 22 September to 22 March). Students are divided into team-groups, not depending on the classes, but depending on which book they are studying . The lesson is based on the interaction of Mudarris and the student. The Arabic text on the subject under study in Bunda was interpreted by Mudarris with examples and discussed among themselves with the participation of students, but in many cases it was difficult to understand the essence of the issue . As guides are mostly in Arabic.

The curriculum of the madrassas of Central Asia was mostly formed in the Middle Ages. Training literature reflects the centuries-old culture of the Islamic world. For example, "Shamsiya" (official book of logic) and its commentaries in the XIII century, "Aqoid" (the book explaining the Islamic doctrine) in the 12th century, "Logic Tahzib" (a dialectical book that contains Arabic interpretation of Greek philosophy) in the 16th century. The Shariah (a collection of rules and ethics based on the Holy Quran and holy tradition) was created in the 8th and 9th centuries.

In the curriculum of the madrasas, Arabic language is a major part of the curriculum and is taught step by step. The commentary of Ibn Hajib (1175-1249) on Al-Qafiya by Abdurahman Jomi (1414-1492), a book by Sharhi Mullah, was used to master Arabic grammar.

In addition, in madrasahs, the science of logic and its interpretations, the science of the word and the comments written on it, dialectics, metaphysics, philosophy, hadiths, comments to the Kuran Karim, the science of Fiqh, that is, a lesson from the right to Islam . 
Each of the above-mentioned Sciences was read on the basis of certain books and reviews written on them. For example, the main guide on the basics of Islamic teaching was the work of Nasafi "Aquid", written in the 12th century, this guide was studied for him on the basis of reviews compiled by Taftazoni in the 14th century. The main guide to the basics of Fiqh was the four-volume work "Hidoya" by Burhoniddin Marginani, which was also read mainly on the basis of the reviews written on it.

The learning process also required a thorough study of the books Ilmi Kalam, Ilmi Faroiz (Heritage Law), and Scientific Science. In the study of inheritance rights, it was necessary to study mathematics to calculate property.

It also provides short and general information on logic, geography, history, physics and natural sciences.

In general, in order to complete the full course of study in Madrasahs the student had to read and master several dozen collections of textbooks, manuals and reviews. Most of the sciences consisted of religious knowledge. Most of the religious literature was in Arabic.

From secular knowledge taught the basics of arithmetic in madrasahs (four practices), the basics of geometry (calculation of the triangular and rectangular face), the concept of nature (definition of the seven climates), the logic for the formation of the qualification for the analysis of the contents of the mentioned books, the basics of astrology .

Some of the literature mentioned in the madrasah is in Persian and local Turkic languages, which are mastered by dictionaries, grammar rules of these languages are not mastered, they are read and interpreted by the teachers.

Most of the hands in the religious direction were composed of comments written in the main books . Because by this period there was a period of vigilance in the educational process, that is, comment on the comment and study them . Rhyme-means to write a comment, commenting on some sentences and words that are difficult to understand in the text to the edge of the book, that is, to the frame. Margins are written in almost every book. In each of the individual books, the margins were written on 10-15 soles, so that the students of the madrasah spent time until 7-10 years to master them.

According to Abdurauf Fitrat and Sadriddin Aini, contemporaries of Bukhara, during the reign of Amir Muzaffar in madrasahs, attention was drawn to the basic sciences, particularly the interpretation of the Qur'an and Jadid. During Amir Abdulahad, however, the process became even more formal and official commentary was completely lost, with the emphasis on book debates and reading, and the student did not even read the Qur'an and the Jadid for 18-20 years.

As a result, not only the student, but also the Mudarris himself, remained the main book and spent time studying the commentaries and frameworks written on it, as a result of which the primary sources such as Qur'anic interpretation, Jadid, Fiqh, method Fiqh were not mastered due to lack of time . And this, in turn, led to the weakening of religious enlightenment, to the decline of fanaticism. This was one of the factors that led to the weakening of knowledge in the educational system of madrasahs at that time . However, by this period, in the majority of madrasasahs of other Muslim countries, the Mudarris refused to be sentimental.

Even in the textbooks of the Arabic language, reviews and comments have taken a great place. A student studying the Arabic alphabet in primary school had to deeply master the Arabic language morphology ("Sarf"), lexicon and syntax ("Nahv") in madrasa . Since the Arabic language, which is the main language tool for mastering religious knowledge, in particular Islamic fundamentals, Sharia law, has not been used in everyday life at all, its deep appropriation has been much more complicated for most students, with the exception of the few, highly educated students.

Therefore, the study of Arabic literature with the help of Dictionaries made the process of their mastering more complicated. In such circumstances, it was rather difficult to deeply master the laws of Sharia, to conduct a broad discussion about their essence and practice, to associate theoretical knowledge with real life. It is for this reason that most of the students have spent their years in order to complete their studies in madrasahs or have not successfully completed it.

Because of these problems, the educational process in the madrasasahs is complicated and protracted. On top of this, the fact that in the educational system a large part of religious literature is dominated by essays, interpretations has led to a narrowing of secular disciplines in the educational program.

Because of these problems, the educational process in the madrasasahs is complicated and protracted. On top of this, the fact that in the educational system a large part of religious literature is dominated by essays, interpretations has led to a narrowing of secular disciplines in the educational program.

Abu Nasir al-Kursawi, a Tatar scholar who had come to Bukhara from Kazan and trained in the well-known sheikhs of the Mujaddadi teaching, was one of the first scholars to initiate this. Abu Nasir alKursawi, in 1808-1809, defended his views in a meeting of scholars with the Emir of Bukhara Amir 
Haidar and was convicted of atheism. Abu Nasir al-Kursavi, who was released at the request of his teachers in Bukhara, returned to Kazan shortly.

Another Tatar nation, Shahabuddin Marjani (Shahabuddin Marjani), who studied Arabic, Persian, Eastern philosophy and history, astronomy and mathematics in the 30-ies of the XIX century, studied at the Bukhara and Samarkand madrasahs. Continue the reform ideas of Abu Nasir Al-Kursawi, develop a program of reforming the education system in madrasahs.

In the Shahabuddin Marjani program, the madrasahs were proposed to reduce the lessons devoted to essays and commentaries in the training courses, instead of introducing lessons such as Kuran Karim, translation of Jadids, Islamic history, more extensive teaching of arithmetic, geography, medicine, geometry, logic, philosophy and other secular sciences. But these proposals were not recognized by the scholars and the Amir government in a conservative spirit, faced with their sharp resistance and were not taken into account in due time.

At the turn of the 20th century, within the traditional system of education, the process of framing increased. Most of the hours were spent in essays, commentaries, or textbooks on Islamic foundations, written by different authors at different times. As a result, the hours of basic sciences, not only secular but religious, were reduced. Though this was strongly criticized by the progressive intellectuals, the scholars of religion did not make any difference.

However, despite the opposition, some teachers in the country, especially the head of the Abdullahan madrassah, Domla Najmiddin and the head of the Saraii Gisht madrassah, refused to give a lecture and began to teach the Qur'an and Hadith. However, this did not become public due to the opposition of fanatics.

Official government response to local education systems. In the policy pursued by the official government over non-Russian peoples under the Russian empire, the plans for eradicating the local population through educational institutions were set in the early years of the colonial system. In particular, from the earliest years of the Turkestan governorship, in 1869-1870, under the leadership of Minister of Public Education of the Russian Empire, D.A. Tolstoy, the goal of expanding the primary school system among the Volgaboi, Ural, Siberia and the Crimea was to educate non-Russian-educated people on the following: and mixing with the Russian people."

General-Governor K.The P.Kaufman in his letter to the chairman of the Missionary Society in 1869 year emphasized that "it is possible to put the religion of the people on their own rather than to carry out missionary activities in the country, to promote ideas that correspond to the sacred teachings of the Christian religion through schools, thereby losing the charm of the Muslim religion". In fact, Turkestan has made a plan to achieve its influence by applying a policy of indifference and neglect of the Islamic religion.The P.Kaufman's plans to use the local education system in the colonial interests were very large. In 1870, general-Governor K.The P. According to the order of Kaufman, in the conclusion of the special commission on the establishment of the education system in Turkistan, as well as K.The P. The project "Organization of the educational department and public education in the Turkistan region", presented by Kaufman to the government of the Empire in 1873, emphasizes the ideas that "education of the people in the country should be established and developed on the basis of Russian interests". In his opinion "it was necessary to" educate the Turkestan youth together with Russian children, to eliminate the difference in the thinking of unusual children and lead to positive results These ideas have served as the basic principle of holding the education system in the country. K.P. Kaufman argued that Muslim educational institutions were "both religious and political," and feared that their activities would be completely disrupted. Therefore, he strongly believed that as a result of a policy of neglecting and neglecting local educational institutions, they would disappear like Islam. In the assimilation of the conquered country". However, the policy of getting rid of indigenous schools and madrassahs neglected failed. The schools were not in short supply, and their numbers increased proportionally to the population.

In this situation, in order to take the local schools in the country under the control of the administration, in 1875, the main Department of educational affairs of Turkistan will be established, and all educational institutions in the country will be transferred to its control. In 1890, the post of people's educational institutions and two more special positions for educational institutions in the regions of Sirdarya, Fergana and Samarkand will be introduced. For the position of director of public educational institutions V.The P. Nalivkin is appointed. On his initiative, starting from 1891 year, the order of appointment, dismissal, control of madrasasahs of Madrasah Mudarris was established by the Chief Executive Officer. According to the decree of December 3, 1913, the possession of the appropriate license of the educational department for the teachers to teach in madrasah was defined as an obligatory procedure.

In order to develop a new policy in relation to Muslim schools and madrasahs, the establishment of local educational institutions on the basis of the proposal of special commissions established in 1905, 1908, 1909 was also carried out with the permission of educational institutions. 
According to a number of laws and orders of the colonial administration adopted in 1886, 1891, 1902 and 1906, the issues of foundation, namely the administration of waqf revenue, the control, appointment and dismissal of the activities of the trustees, are also entrusted to the inspections and regional departments.

Thus, not only the establishment and activities of traditional educational institutions, but also the financial support of private charities, are also under the control and control of the administration.

The administration, which was heavily criticized by the press, the official correspondence, and the special commissions' problems at the time, was far from the idea of taking practical steps to rectify the situation, but rather for the administration to maintain it. Responding to a critical written statement from the governor of the Ferghana region on the state of education in the madrassas of Margilan, "It must be so, because this is in line with the policy of the emperor", which clearly reflected the administration's policy towards the local education system.

Primary Education Reforms. The progressive minds of the time realized that the method and level of education in elementary school were lagging behind modern requirements. The problem of improving and reforming the methods and programs of education, conditions and material provision in schools had become a topical issue of social and spiritual life in the early 20th century. M. Behbudi's book "To live in the world requires worldly science and knowledge; a nation incompatible with the science and science of our time.

New method schools. By this period, the rapid socio-cultural development in Europe began to resonate even in the Muslim world.The influence of these processes was most strongly manifested in the Ottoman state of avvlo. Educational reforms, which were one of the important and urgent tasks in the activities of Young Turks who came to the political arena in this country in the second half of the XIX century, at a short opportunity spread to the Volga, the Crimean Peninsula, and at the beginning of the XX century also reached Central Asia.

In 1884 in Crimea, in Bogchasaroy. Gaspyrinsky's new school of methodology gained popularity and popularity in the Muslim community when it was proved that sound training, such as letter-based learning (tactics), could be produced quickly and easily.

Gaspirinsky soon established 30 schools in Russia based on this method and created a new textbook for them, called the "Khojai Sibyon". Classes in these schools were organized according to the timetable and the rooms were equipped with amenities (desks, tables, chairs) for students and teachers;

A similar school in Central Asia was first established in 1884 by the palace of Khiva's khan, Said Muhammad Rahim Khan Feruz. Russian artist L. According to Dmitriev-Kavkazsky, his classroom had a large geographical map on the wall, books on his shelves, ink on the table, and two seats next to it. But it was only for the children in the Khan's Palace. The learning process continued in the traditional way.

In 1892 I. Gaspirinsky wrote a letter to the governor-general of Turkestan, stating that the new schools he founded would allow them to be literate in 1.5-2 years instead of 6-7, and would ask for help in establishing such schools in the country.

But by the governor-general, N.P. Ostroumov and V.P. The proposals in this letter submitted to Nalivkin for consideration are considered "contrary to colonial interests," and are therefore ignored.

Gaspirinkiy, who came to Turkestan in 1893, with his friends here, established the first new method schools in Samarkand and Bukhara. Such schools, which have received positive results from the local population, are known as the "Jadids", that is, the new method schools and will soon become popular.

In 1893 the first new schools were opened in Kokand and Samarkand, and later in Tashkent and Andijan. Originally created for children of Tatar families in Turkestan, the new schools will soon attract the attention of local children and educators. At the beginning of the 20th century, the creation of new method schools became a pressing problem in the education system, and such schools began to spread throughout the country.

Dozens of new methods schools operated in the cities of the Fergana Valley. Along with the cities of Andijan and Kokand, new schools will be established in some villages as well.

Some schools are based on old schools. The largest new school in Andijan could accommodate more than 100 students. There were more than ten new schools in Kokand.

The new methodology school opened in Samarkand is not only a four-year elementary school but also a four-year secondary school. Classes in this school were organized in 1906 based on a program developed in Kazan. The role of Abdulkadir Shakuri played a role in the development of new method schools in Samarkand. His school, founded in 1903, teaches Arabic, Persian, Russian, and textbooks for students.

More than a dozen new schools were opened in Tashkent. Munavvarqori Abdurashidkhanov, who began his first work in 1905, received official permission to open a new method school in Tashkent. and the basics of religious education. The school quickly gained fame and popularity. In a short period of time there were 30 such schools established in Tashkent and in different provinces of Turkestan 
governorship. New textbooks for these schools were created by Munavvarqori Abudrashidkhanov, Mahmudkhoja Behbudiy and Abdulla Avloni.

Teaching religious and secular subjects in the schools of the New Methodology, teaching the basics of Islam, focusing on moral education, giving great importance to Arabic as a native language, teaching natural sciences, geographical knowledge, and arithmetic operations in the curriculum included up to 100 calculations and compilations of Russian authors. school), 4-year mastering of the program, installation of globes, maps, modern classroom equipment (desks), and most importantly, positive results of students. lifted the nose. By 1917, there were about 100 new method schools in the country.

New methods have become more commonplace, and the authority of the old schools has begun to decline. This led to the discontent of some fanatical scholars and aggravated their sentiments. On January 3, 1914, Saidakhmad Siddiqi's mosque in the mosque of the Mirzo Ulugbek madrassah in Samarkand was declared a "disbeliever" for the opening of a new school, the dismissal of Sufizadeh's teacher from Chust, and a Tashkent order to kill Mirmuhsin Shermuhamedov by a city judge. was a clear example of the discontent of conservative forces against the reform.

Not only in Turkestan, but also in the Emirate of Bukhara. The fanatical mullahs here require the government to close schools again. Concerned about the rise of anti-government forces, Miras Nasrullobek Kushbegi issued a decree prohibiting Bukhara from entering a new school. Parents were warned and children were taken out of school. Amir Abdulahad Khan has received permission from the governor general of Turkestan to complete a new school in Bukhara. But the interest in new schools did not disappear, and they started to operate underground.

\section{CONCLUSION}

In conclusion, at the beginning of the 20th century, Uzbekistan's education system, which is an important area of traditional cultural life, lagged behind modern requirements and the need for reform increased. But the novelty of old, the intense struggle and conflicts between the progressive and the fanatical forces and the colonialists, have been a serious obstacle to these processes. That is why educators of Turkestan urged that every advanced man of the world should know, first and foremost, his native language, Arabic, Persian, and one of the Russian and European languages in order to understand his own culture.

Attempts to reform the traditional education system by local educators were not acceptable to the administration. The new method schools in particular were of great concern to the government. Representatives of the provincial government were openly proposing in the press of the time that the new method schools should be completely controlled. In particular, N. H.Ostroumov expressed concern that Jadids schools are gaining popularity among the population, emphasizing that "all of a sudden these schools fully meet the needs of the local people and cannot be indifferent to this process." . N. Ostroumov acknowledged that the behavior, humility, respect for the children and their upbringing, the firmness of family rules and traditions, and that "a new generation of locals had advanced far ahead of their Russian ancestors," emphasized how "their mood is important to the government." "And calls for the closure of the new-style schools.

By that time there were more than 100 "new methods" schools in Turkestan with 10,343 students enrolled. Fearing that the new method schools would help grow the national culture and label them "dangerous", the imperial administration sought to limit such schools as much as possible and control them. The Orders of 1909, 1911 and 1912, adopted by the Special Commission under the Office of Educational Affairs, were intended to strengthen control over the new method schools.

In 1911, the province's administration closed dozens of new schools on the pretext of firing Tartar teachers in primary schools in an effort to lessen the impact of Tatar intellectuals on the local population. In 1912 the governor-general of Turkestan enacted measures to strengthen the control of educational institutions on the new method schools. As a result of these measures, more than 50 new schools were closed during the 1910-1911 school year. Thus, the traditional education system, which has existed for centuries, has been resisted by the colonial administration since the early 20th century. The colonialists, claiming to bring civilization to the region, criticized the problems here, but tried to prevent it as much as possible and prevented its efforts.

Consequently, in the second half of the 19th and the beginning of the 20th centuries, the education system in Turkestan needed a number of reforms, such as the analysis and solution of a number of problems.

\section{REFERENCES}

1. ั з̆Р МДА И-1 жамғарма, 11-рўйхат, 1-йиғмажилд, 14-варақ.

2. ั з̆Р МДА И-47 жамғарма, 1-рўйхат, 382-йиғмажилд, 8-варақ. 
3. ЎзР МДА И-47 жамғарма, 1-рўйхат, 926-йиғмажилд, 101-варақ.

4. ЎзР МДА, 47 жамғарма 1-руйххат, 955 йиғма жилд, 259-в.

5. ЎзР МДА, И-1 жамғарма, 27-рўйхат, 1207-йигма жилд, 1-13-варақ.

6. ЎзР МДА, И-1-жамғарма, 27-рўйхат, 1207-йигма жилд, 1-13-варақлар.

7. ЎзР МДА, И-461-жамғарма, 1-рўйхат, 1720-йиғма жилд, в. 76.

8. Abdullaev I. Eski maktabda xat-savod o'rgatish. - Toshkent, 1961.

9. Ayniy S. Asarlar. 1-jild. - Toshkent, 1963.

10. Ayniy S. Asarlar. 5-tom. - Toshkent, 1965.

11. Ayniy S. Asarlar. 6-tom. - Toshkent: Badiiy adabiyot, 1965.

12. Ayniy S. Buxoro inqilobi tarixi uchun materiallar. - M., 1926. B. 31 va h.k.

13. Bendrikov K. E. Ocherki po istorii narodnogo obrazovaniya v Turkestane 1865-1924 gg. Moskva: Nauka, 1960.

14. Behbudiy M. Tanlangan asarlar. Toshkent: Ma’naviyat, 1999.

15. Behbudiy M. Til masalasi // Oyina. 1915. № 11, 12. B. 274-277, 306-311.

16. Vamberi G. Puteshestvie po Sredney Azii. S. 179-181.

17. Geyer I. I. Turkestan. Tashkent, 1909. S.25.

18. Girshfeld G. Voenno-statisticheskoe opisanie Xivinskogo oazisa. CH. II. Tashkent, 1903. S. 137.

19. Gramenitskiy S. Inorodcheskoe obrazovanie . 1900. №3

20. Gramenitskiy S. Inorodcheskoe obrazovanie v Turkestanskom krae. 1900. №1

21. Gramenitskiy S. Polojenie inorodcheskogo obrazovaniya v Sir'-Darinskoy oblasti. - Tashkent, 1916. S. 26-27;

22. Dmitriev - Kavkazskiy L.E.. Po Sredney Azii. Zapiski xudojnika.- SPb., 1894. S. 70.

23. Donish A. Navodir ul-vaqoe. - Toshkent, 1964. B. 58.

24. Ziyaeva D. Rol gorodov i transformatsiya v torgovix svyazax Uzbekistana s Kitaem (2-polovina 19 - nachalo 20 vekov) // 1400th anniversary of Tang's capital Chang'an (Belt and Road Initiative). Xi'an (CHINE) 2018. P. 212-215.I

25. Ziyaeva D. Russkie duxovno-kulturnie i blagotvoritelnie obщestva v gorodax Turkestana. // Rossiysko-Uzbekistanskie svyazi v kontekste mnogovekovoy istoricheskoy retrospektivi. T. 2013. - S. 224-231.

26. Ziyaeva D. Transformatsiya traditsionnoy gorodskoy ekonomiki Buxari v konse XIX - nachale XX vv. // Sentralnaya Aziya: chelovek, obщestvo i gosudarstvo. Rossiyskaya Akademiya nauk Institut vseobщey istorii. Moskva. 2013. Sbornik statey. S.225-234

27. Ziyaeva D.Novovvedeniya $\mathrm{v}$ traditsionnom jilishe gorodskogo naseleniya Uzbekistana. / $\mathrm{X}$ Kongress etnologov i antropologov Rossii. Moskva. 2013. Seksiya 18. Gorodskaya kultura Sentralnoy Azii: Istoriya i sovremennost. S.110.

28. Ziyaeva D.X. The environmental problems of the cities in contemporary Uzbekistan // The social history and anthropogenic landscape of the Syrdarya River Basin: Exploring an environmental Archive. Tashkent, 18-19 April 2016. - P. 23.

29. Ziyaeva D.X. Intellektualnoe nasledie Uzbekistana XIX - nachala XX vv. v kontekste vzaimovliyaniya zapadnoy i traditsionnoy nauki // Istoriya i istoricheskaya pamyat: mejvuz. sb. nauch. tr. [pod red. A.V. Gladisheva.] - Vip.17. - Saratov: Sarat. gos. un-t, 2018. S.68-72.

30. Ziyaeva D.X. Intellektualnoe nasledie Uzbekistana XIX - nachala XX vv. v kontekste vzaimovliyaniya zapadnoy i traditsionnoy nauki // Istoriya i istoricheskaya pamyat: mejvuz. sb. nauch. tr. / pod red. A.V. Gladisheva. - Saratov: Sarat. gos. un-t, 2018. - Vыp. 17. - S.68-72.

31. Ziyaeva D.X. Intellektualnoe nasledie Uzbekistana v XIX-nachale XX vekov // 1-Forum gumanitarnix nauk "Velikaya Step". International Turkic Academy. Astana, Kazaxstan. 2017.

32. Ziyaeva D. Traditional medicine in Turkestan at the end of XIX-at the beginning of XX centuries // ESCAS-CESS joint conference, June 29-July 2, 2017, Bishkek, Kirgizstan

33. Ziyaeva D. Written Sources of Intellectual Heriatage of Uzbekistan in 19th -20 th // Sivilizatsii velikogo shelkovogo puti iz proshlogo v buduщee: perspektivi estestvennix, obщestvennix, gumanitarnix nauk. P. 386-393.

34. Ziyaeva D. Sovetskaya Politika "Natsionalizatsii" i "Raskulachivaniya" v Uzbekistane. // 100. yilinda sovyet ihtilali ve Türk dünyasi. ANQARA.189-197. s. 2018. 
35. Ziyaeva D.H. Education and culture in Tashkent. // Himalayan and Central Asian Studies (Uzbekistan Special). DEHLI. 2015.

36. Ziyayeva D. Kh. The Sources on the History of Intellectual Heritage in Uzbekistan. // Halaqa: Islamic Education Journal 2(1), June 2018. P.117-123.

37. Ziyayeva D.Kh. School of traditional historiography in Kharezm: history and features of development // Academicia: An International Multidisciplinary Research Journal (Double Blind Refereed \& Reviewed International Journal). Vol. 9 Issue 7, July 2019. P. 30-37.

38. Ziyayeva D.X. Main arias of researches in the field of natural sciences in the XIX - early XX centuries // Multi disciplinary scientific journal "Archivarius" collection of scientific publications. Kiev 2019. P.24-32.

39. Ismailov SH.SH. Narodnoe obrazovanie v Uzbekistane v konse XIX - nachale XX veka. Avtoref. dis. ... kand. ist. nauk. Tashkent, 1981. S.15.

40. Kari - Niyazov T.N. Ocherki istorii kulturb Sovetskogo O‘zbekistana. - M., 1955. S. 58.

41. Kari - Niyazov T.N. Progressivnoe znachenie prisoedineniya Turkestana k Rossii. ... S.65. (bu kitobdan asl manbani topish kerak)

42. Kaufman K.P. Proekt vsepoddanneyshego otcheta general-ad'yutanta K.P. fon Kaufmana po grajdanskomu upravleniyu i ustroystvu $\mathrm{v}$ oblastyax turkestanskogo general-gubernatorstva. 7.XI.1867. - 25. III. 1881. (sost. P.I. Xomutov). SPb., 1885. VIII gl. otcheta perepechatana v kn.: Kaufman K.P. Nachalnoe narodnoe obrazovanie v Turkestanskom krae. 1881. SPb., 1910. S.437-438.

43. Kerenskiy F.M. Medrese Turkestanskogo kraya // Turkestanskiy sbornik. Tom 418. Tashkent, 1907. S.25.

44. Qosimov B. Milliy uyg'onish. Toshkent, 2002. 20-21-bet.

45. Qosimov B. Turkistonda jadid maktablari. - Toshkent, 2006

46. Nazimov A. Qizlar tarbiyasi. Toshkent: "Kamalak", 1994. 64-bet.;

47. Nalivkin V. P. Chto dayot sredneaziatskaya musulmanskaya shkola. S. 240.

48. Nalivkin V. P. Shkola u tuzemsev Sredney Azii.// Turkestanskie vedomosti.

49. Niyoziy Rajabzoda. Ko'rsatilgan asar ??? // Oyina. 1914, № 38.

50. Oyina. 1914, № 12.

51. Oyina. 1914. № 17.

52. Oyina. 1914. № 38 .

53. Olimat ul-banot. Muosharat odobi. Toshkent: Mehnat, 1997. 32-bet.

54. Ostroumov N. P. Islamovedenie // Vvedenie v kurs islamovedeniya. - Tashkent, 1914. S. 167.

55. Ostroumov N. P. Musulmanskie maktabi i russko-tuzemnie shkoli v Turkestanskom krae // Turkestanskiy sbornik. T. 418. - Tashkent, 1908. S. 77.

56. Ostroumov N. P. Chto delat s novometodnimi maktabami? // Turkestanskie vedemosti, 1909. №1.

57. Ostroumov N. P. Chto delat s novometodnimi maktabami? // Turkestanskiy sbornik. T. 497. Tashkent, 1909. S. 97-99.

58. Pavlovskiy E.N. Ocherki Samarkandskoy oblasti. (S risunkami v tekste) // Turkestanskiy sbornik. T.554. Tashkent, 1915. S.53.

59. T.XI Svoda zakonov. Otdelenie vtoroe. Ob upravlenii uchebnimi zavedeniyami v Turkestanskom krae. S.89.

60. Turkestanskie vedomosti. 1878, № 16.

61. Turkestanskie vedomosti. 1898, 8 avgusta, № 32 .

62. Turkestanskie vedomosti. 1898, 8 avgusta, № 32;

63. O‘zbekiston milliy ensiklopediyasi. 10-jild, Toshkent: Davlat milliy nashriyoti, 2005. 384-bet.

64. Fitrat A. Munozara // Sharq Yulduzi. 1997, № 1. B. 149;

65. Fitrat A. Munozara // Sharq yulduzi. 1997. № 1. B. 128, 162.

66. Fitrat A. Hindistonda bir farangi ila buxorolik mudarrisning jadidi maktablari xususida qilgan munozarasi // Tanlangan asarlar. - Toshkent, 2000. 1-jild. B. 255.

67. Fitrat A.. Tanlangan asarlar. 4-jild. - Toshkent, 2006. B. 336.

68. Fitrat A..Tanlangan asarlar. 1-jild. - Toshkent, ??? B. 57. 
69. Xanikov A. Opisanie Buxarskogo xanstva. - Sanktpeterburg': v' tipografii Imperatorskoy Akademii Nauk, 1843. S. 222.

70. Xanikov A. Opisanie Buxarskogo xanstva. - SPb., 1848. S. 88.

71. Xoroshxin A.P. Sbornik statey, kasayuщixsya Turkestanskogo kraya. SPb., 1876 S.91.

72. www.islomqomusi.info 